\title{
WATER AVAILABILITY IN A PLANOSOL UNDER INTEGRATED CROP- LIVESTOCK-FORESTRY SYSTEM IN THE AGRESTE REGION OF PARAIBA, BRAZIL $^{1}$
}

\author{
PEDRO LUAN FERREIRA DA SILVA ${ }^{2}$, FLÁVIO PEREIRA DE OLIVEIRA ${ }^{2 *}$, DANILLO DUTRA TAVARES ${ }^{3}$, \\ CAMILA COSTA DA NÓBREGA ${ }^{2}$, ANDRÉ JULIO DO AMARAL ${ }^{4}$
}

\begin{abstract}
Integrated agricultural production systems, involving agriculture, livestock, and forest are strategies that improve soil quality. The objective of this work was to evaluate the effect of the integrated croplivestock-forest system (ICLF) on water availability of a Planosol in the Agreste region of the state of Paraíba (PB), Brazil. The experiment was conducted at the experimental site of the Agricultural Research Company of Paraíba (EMEPA), in Alagoinha, PB. The soil evaluated was a Eutric Planosol, with a moderate A horizon. The following intercrops (treatments) were implemented in June 2015: I. Gliricidia sepium + Brachiaria decumbens; II. Mimosa caesalpiniifolia + Brachiaria decumbens; III. Tabebuia alba + Brachiaria decumbens; IV. Zea mays + Brachiaria decumbens; and V. Brachiaria decumbens. A randomized block experimental design was used, with five treatments. The analyzed variables were field capacity, permanent wilting point, soil available water, granulometry, degree of flocculation, total porosity, macroporosity, microporosity, saturated hydraulic conductivity, resistance to penetration, and aggregate stability index. The results showed that the water availability in the ICLF implemented in the Agreste region of Paraíba had no significant variation after three years. After the three-year period, the ICLF promoted no significant physical improvement in the attributes of the evaluated Planosol.
\end{abstract}

Keywords: Water retention. Soil available water. ICLF.

\section{DISPONIBILIDADE DE ÁGUA EM PLANOSSOLO SOB SISTEMA DE INTEGRAÇÃO LAVOURA- PECUARIA-FLORESTA NO AGRESTE DA PARAIBA}

\begin{abstract}
RESUMO - Os sistemas integrados de produção agropecuária, envolvendo lavoura, pecuária e floresta (ILPF) são estratégias que promovem a qualidade do solo. Objetivou-se com esse trabalho avaliar a influência do sistema de integração Lavoura-Pecuária-Floresta na disponibilidade de água em um Planossolo na mesorregião do Agreste da Paraíba. O experimento foi conduzido na estação experimental da Empresa de Pesquisa Agropecuária da Paraíba (EMEPA), em Alagoinha (PB). O solo é um Planossolo Háplico, horizonte A moderado.Em junho de 2015, foram implantados os seguintes consórcios: I. Gliricídia (Gliricidia sepium (Jacq.) Steud.) + Brachiaria decumbens; II. Sabiá (Mimosa caesalpiniifolia) + Brachiaria decumbens; III. Ipê amarelo (Tabebuia alba (chamiso) sandwith) + Brachiaria decumbens; IV. Milho (Zea mays L.) + Brachiaria decumbens; V. Brachiaria decumbens. Utilizou-se o delineamento de blocos casualizados (DBC), com cinco tratamentos. As variáveis analisadas foram: capacidade de campo - $\theta_{\mathrm{CC}}$, ponto de murcha permanente - $\theta_{\mathrm{PMP}}$, água disponível - $\theta_{\mathrm{AD}}$, granulometria, grau de floculação (GF), porosidade (total - $\alpha$, macro - Ma e micro - Mi), condutividade hidráulica saturada $-\mathrm{K}_{\theta}$, resistência a penetração - Rp, índice de estabilidade de agregados - IEA. De acordo com os resultados observa-se que a disponibilidade de água na integração lavoura-pecuária-floresta implantada no agreste paraibano não apresentou variação significativa após um período de três anos. A integração, após o período de três anos, ainda não promoveu melhoria física significativa dos atributos do Planossolo em estudo.
\end{abstract}

Palavras-chave: Retenção. Água disponível. ILPF.

\footnotetext{
*Corresponding author

${ }^{1}$ Received for publication in $08 / 31 / 2018$; accepted in $03 / 12 / 2019$.

Paper approved from III SINPROVS 2018

Paper extracted from the first author of the Scientific Initiation Project - PIBIC / CNPq.

${ }^{2}$ Department of Soils and Rural Engineering, Universidade Federal da Paraíba, Areia, PB, Brazil; pedroluanferreira@gmail.com - ORCID: 0000-0001-5520-7920, pereira@cca.ufpb.br - ORCID: 0000-0001-7968-6145, camila cnobrega@hotmail.com - ORCID: 0000-0001-77544338 .

${ }^{3}$ Department of Agronomy, Universidade Federal Rural de Pernambuco, Recife, PE, Brazil; danilodutrat@hotmail.com - ORCID: 00000001-7763-6793.

${ }^{4}$ Embrapa Solos, Recife, PE; Brazil; andre.amaral@embrapa.br - ORCID: 0000-0001-7246-2974.
} 


\section{INTRODUCTION}

Monitoring soil moisture is a very important tool for the study of water dynamics and rational planning of water management in agricultural activities (ALMEIDA et al., 2017), especially in irrigated agriculture. Water retention is one of the variables to be considered for soil water management since it is strongly altered by inadequate cultivation practices, especially in poor soil physical conditions (SANTOS et al., 2013b).

Livestock overcrowding, inadequate management of pastures, and lack of soil conservation practices, pest and weed control, and soil fertilization or soil fertility maintenance in the Brazilian Northeast (KICHEL et al., 2011) have been the most important factors for the degradation of pastures.

Therefore, adopting management systems that enhance the soil water retention and water availability to plants is necessary, especially in regions where the economy is essentially agricultural and its development depends on climatic conditions (KLEIN; KLEIN, 2015).

Integrated productions provide greater stability and sustainability for agricultural systems than intensive monocultures, which are not sustainable and negatively affect soils and local biodiversity. The integrated crop-livestock-forest system (ICLF) emerges as an alternative for soil recovery and conservation in degraded areas (SILVA et al., 2016) by enhancing the synergistic effects between plant and animal species used, enabling a sustainable increase in the production per area (BALBINO et al., 2011).

ICLF can bring several benefits, especially formation and stability of soil aggregates; soil permeability; development of root system of plants (COSTA et al., 2012); reduction of incidence of solar radiation, temperature, and evaporation in the soil; and prevention of soil surface sealing (SILVA et al., 2014).

ICLF is also efficient in increasing and maintaining soil organic matter and nutrient cycling
(FACCIN et al., 2016) and improves soil physical attributes when compared to traditional systems of soil use, in which crop sand pastures are grown singly (LOSS et al., 2014). The development of different activities in the soil alters its properties, especially structure, improving its porosity and, consequently, water retention capacity (SERRA et al., 2012).

Researches on integration systems in the state of Paraíba (PB), Brazil, are incipient, but already presenting satisfactory results (RANGEL et al., 2016). However, few studies give information on the impact of adopting ICLF on soil physical quality in the Northeast region of Brazil, thus, studies on soil physical parameters that can serve as reference for the implementation of these systems are necessary.

The objective of the present work was to evaluate the effect of ICLF on water availability of a Planosol in the Agreste region of Paraíba, Brazil.

\section{MATERIAL AND METHODS}

The experiment was conducted at the experimental station of the Agricultural Research Company of the state of Paraíba (EMEPA), in Alagoinha, PB, Brazil (06 $57^{\prime} 00^{\prime \prime} \mathrm{S}, 35^{\circ} 32^{\prime} 42^{\prime \prime} \mathrm{W}$, and altitude of $317 \mathrm{~m}$ ). The climate of the region is As', hot and humid, with autumn-winter rains, according to the Köppen-Geiger classification. The average annual rainfall is $995 \mathrm{~mm}$, with a rainy season from March to August; the average annual temperature varies from $22^{\circ} \mathrm{C}$ to $26^{\circ} \mathrm{C}$; and the average relative air humidity is approximately $25 \%$.

The soil of the experimental area was classified as a Eutric Planosol (SANTOS et al., 2013a), presenting moderate A horizon, sandy loam texture, slightly undulating to undulating relief, and semiarid sub-deciduous forest.

Soil samples $(0.0-0.20 \mathrm{~m}$ layer $)$ were collected, packed in plastic bags, air dried, disaggregated, and sieved in a $2 \mathrm{~mm}$ mesh sieve for physical and chemical characterization (Tables 1 and 2).

Table 1. Physical characterization of the Eutric Planosol before the implantation of the experiment.

\begin{tabular}{|c|c|c|c|c|c|c|c|c|}
\hline Sand & Silt & Clay & CDW & DF & SD & PD & $\mathrm{TP}$ & Textural Class \\
\hline & 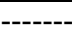 & $\mathrm{kg}^{-1}-$ & & & $---g$ & & $\mathrm{~m}^{3} \mathrm{~m}^{-3}$ & \\
\hline 685 & 172 & 143 & 38 & 73.4 & 1.54 & 2.64 & 0.42 & Sandy loam \\
\hline
\end{tabular}

$\mathrm{CDW}=$ clay dispersed in water $\mathrm{DF}=$ Degree of flocculation; $\mathrm{SD}=$ Soil Density; $\mathrm{PD}=$ Particle density; $\mathrm{TP}=$ Total porosity.

Table 2. Chemical characterization and fertility of the Eutric Planosol before the implantation of the experiment.

\begin{tabular}{cllllllllll}
\hline $\mathrm{pH}_{(\mathrm{H} 2 \mathrm{O})}$ & $\mathrm{P}$ & $\mathrm{K}^{+}$ & $\mathrm{Na}^{+}$ & $\mathrm{H}^{+}+\mathrm{Al}^{3+}$ & $\mathrm{Al}^{+3}$ & $\mathrm{Ca}^{+2}$ & $\mathrm{Mg}^{+2}$ & $\mathrm{SB}$ & $\mathrm{CEC}$ & $\mathrm{TOC}$ \\
\hline$(1: 2.5)$ & $--\mathrm{mg} \mathrm{dm}^{-3}--$ & ---1.0 & 0.03 & 4.46 & 0.00 & 2.71 & 1.17 & 4.41 & 8.87 & 9.10 \\
5.7 & 6.98 & 194.00 & 0.03 & \\
\hline
\end{tabular}

$\mathrm{SB}=$ Sum of bases CTC $=$ Cation exchange capacity; $\mathrm{TOC}=$ total organic carbon. 
The experiment was conducted in a randomized block design, with five treatments and four replications. The following intercrops (treatments) were implemented in June 2015: Gliricidia sepium + Brachiaria decumbens (GS+BD); Mimosa caesalpiniifolia + Brachiaria decumbens (MC+BD); Tabebuia alba + Brachiaria decumbens (TA+BD); Zea mays + Brachiaria decumbens (ZM+BD); and Brachiaria decumbens (BD). The evaluation area of each experimental plot was $760 \mathrm{~m}^{2}(38 \times 20 \mathrm{~m})$.

Disturbed and undisturbed soil samples were collected from two layers $0.00-0.10 \mathrm{~m}$ and $0.10-0.20$ $\mathrm{m}$. The disturbed samples were air dried, disaggregated, and sieved in a $2 \mathrm{~mm}$ mesh sieve to determine their granulometry, degree of flocculation, and clay dispersed in water, according to the manual of methods for soil analysis (DONAGEMA et al., 2011). The undisturbed soil samples were used to evaluate the soil total porosity, macroporosity, microporosity, hydraulic conductivity, resistance to penetration, field capacity, permanent wilting point, and available water.

The total porosity $\left(\mathrm{m}^{3} \mathrm{~m}^{-3}\right)$ was determined through the saturation volume, according to Equation 1:

$$
s v=(a-b) / c
$$

where $s v$ is the saturation volume $\left(\mathrm{m}^{3} \mathrm{~m}^{-3}\right) ; a$ is the weight of the saturated soil block $(\mathrm{kg}) ; b$ is the weight of the soil block dried at $105{ }^{\circ} \mathrm{C}(\mathrm{kg}) ; c$ is the cylinder volume $\left(\mathrm{m}^{3}\right)$.

Macroporosity $\left(\mathrm{m}^{3} \mathrm{~m}^{-3}\right)$ was obtained through the tensile table with a water volume at the matrix potential of $-0.006 \mathrm{MPa}$. Microporosity $\left(\mathrm{m}^{3} \mathrm{~m}^{-3}\right)$ was obtained by the difference between total porosity and macroporosity. Field capacity and permanent wilting point $\left(\mathrm{m}^{3} \mathrm{~m}^{-3}\right)$ were obtained with the aid of the Richards extractor, with water contents retained in the matrix potentials of -0.01 and $-1.5 \mathrm{MPa}$, respectively.

Soil available water was obtained according to Equation 2:

$$
S A W=\theta F C-\theta P W P
$$

where $S A W$ is the soil available water $\left(\mathrm{m}^{3} \mathrm{~m}^{-3}\right) ; \theta F C$ is the soil field capacity $\left(\mathrm{m}^{3} \mathrm{~m}^{-3}\right)$; and $\theta P W P$ is the permanent wilting point $\left(\mathrm{m}^{3} \mathrm{~m}^{-3}\right)$.

Saturated hydraulic conductivity was determined using a constant head permeameter (DONAGEMA et al., 2011), according to Equation 3:

$$
K=(Q \times L) /(A \times H \times t)
$$

where $K$ is the saturated hydraulic conductivity $\left(\mathrm{cm} \mathrm{h}^{-1}\right) ; Q$ is the percolated volume $\left(\mathrm{mL}^{-1}\right) ; L$ is the height of the soil block $(\mathrm{cm}) ; A$ is the cylinder area $\left(\mathrm{cm}^{2}\right) ; H$ is the height of the soil block + water column $(\mathrm{cm})$; and $t$ is the time (hours) for the percolated volume collection.

Soil penetration resistance was obtained with the aid of a laboratory penetrometer (Heavy duty 6T0163), using undisturbed soil samples with moisture balanced at matrix potential of $-0.01 \mathrm{MPa}$. The values obtained in the penetrometer were transformed from $\mathrm{kgf} \mathrm{cm}^{-2}$ to MPa.

The weighted mean diameter of soil dry aggregates (WMDda) was determined according to the methodology described by Silva and Mielniczuk (1997) and the weighted mean diameter of wet aggregates (WMDwa) was determined according to methodology described by Tisdall et al. (1978) and adapted by Carpenedo and Mielniczuk (1990). The aggregate stability index (ASI) was given by the WMDwa to WMDda ratio.

Total organic carbon (TOC) was determined through organic matter oxidation by wetting with potassium dichromate $\left(\mathrm{K}_{2} \mathrm{Cr}_{2} \mathrm{O}_{7}\right)$ in sulfuric medium, using the heat released from sulfuric acid or heating as energy source. The excess dichromate was then titrated with a standard solution - ammonium iron sulfate; $\mathrm{Fe}\left(\mathrm{NH}_{4}\right)_{2}\left(\mathrm{SO}_{4}\right)_{2} \cdot 6 \mathrm{H}_{2} \mathrm{O}$ - and the TOC was obtained using Equation 4:

$$
\text { TOC }\left(g \mathrm{~kg}^{-1}\right)=(40-V) \times f \times 0.60
$$

where $V$ is the volume of the ammonium iron sulfate spent in the titration $\left(\mathrm{mL}^{-1}\right) ; f$ is the correction factor: 40 / volume of ammonium iron sulfate of the blank test.

The data obtained in the characterization of the soil physical attributes were evaluated through analysis of variance. The means were compared by the Tukey's test at 5\% probability, using the SISVAR 5.6 program (FERREIRA, 2000).

\section{RESULTS AND DISCUSSION}

The treatments and the soil layers evaluated in the present work presented no significant variation $(p<0.05)$ for the physical attributes granulometry and degree of flocculation (Table 3 ). However, the sand fraction and degree of flocculation decreased with increasing soil depth. 
P. L. F. SILVA et al.

Table 3. Means for granulometry and degree of flocculation of a Eutric Planosol under integrated crop-livestock-forest system.

\begin{tabular}{|c|c|c|c|c|}
\hline \multirow{2}{*}{ Treatment } & \multicolumn{3}{|c|}{ Granulometry } & \multirow{2}{*}{$\begin{array}{l}\text { Degree of } \\
\text { flocculation }\end{array}$} \\
\hline & Sand & Silt & Clay & \\
\hline & \multicolumn{4}{|c|}{ - } \\
\hline & \multicolumn{4}{|c|}{$0-0.10 \mathrm{~m}$} \\
\hline $\mathrm{GS}+\mathrm{BD}$ & $703 \mathrm{a}$ & $139 a$ & $158 \mathrm{a}$ & $904 \mathrm{a}$ \\
\hline $\mathrm{MC}+\mathrm{BD}$ & $686 \mathrm{a}$ & $152 \mathrm{a}$ & $162 \mathrm{a}$ & 919 a \\
\hline $\mathrm{TA}+\mathrm{BD}$ & $694 \mathrm{a}$ & $143 \mathrm{a}$ & $163 \mathrm{a}$ & $972 \mathrm{a}$ \\
\hline $\mathrm{ZM}+\mathrm{BD}$ & $683 \mathrm{a}$ & $156 \mathrm{a}$ & $162 \mathrm{a}$ & $884 \mathrm{a}$ \\
\hline BD & $681 \mathrm{a}$ & $152 \mathrm{a}$ & $167 \mathrm{a}$ & $819 \mathrm{a}$ \\
\hline \multirow[t]{2}{*}{$\mathrm{CV} \%$} & 7.72 & 14.03 & $\overline{22.66}$ & $\overline{8.44}$ \\
\hline & \multicolumn{4}{|c|}{$0.10-0.20 \mathrm{~m}$} \\
\hline GS+BD & $696 \mathrm{a}$ & $144 \mathrm{a}$ & $160 \mathrm{a}$ & $816 \mathrm{a}$ \\
\hline $\mathrm{MC}+\mathrm{BD}$ & $692 \mathrm{a}$ & $142 \mathrm{a}$ & $166 \mathrm{a}$ & $842 \mathrm{a}$ \\
\hline $\mathrm{TA}+\mathrm{BD}$ & $676 \mathrm{a}$ & $147 \mathrm{a}$ & $177 \mathrm{a}$ & $813 \mathrm{a}$ \\
\hline $\mathrm{ZM}+\mathrm{BD}$ & $695 \mathrm{a}$ & $136 \mathrm{a}$ & $169 \mathrm{a}$ & $862 \mathrm{a}$ \\
\hline $\mathrm{BD}$ & $650 \mathrm{a}$ & $160 \mathrm{a}$ & $190 \mathrm{a}$ & $861 \mathrm{a}$ \\
\hline $\mathrm{CV} \%$ & 7.95 & $\overline{13} .51$ & 21.29 & 9.38 \\
\hline
\end{tabular}

$\mathrm{GS}+\mathrm{BD}=$ Gliricidia sepium + Brachiaria decumbens $; \mathrm{MC}+\mathrm{BD}=$ Mimosa caesalpiniifolia + Brachiaria decumbens; $\mathrm{TA}+\mathrm{BD}=$ Tabebuia alba + Brachiaria decumbens $; \mathrm{ZM}+\mathrm{BD}=$ Zea mays + Brachiaria decumbens $; \mathrm{BD}=$ Brachiaria decumbens; Means followed by the same letters in the columns do not differ by the Tukey's test $(p<0.05)$.

The increase in soil organic matter content and increase in soil volume explored by the roots of the grasses on surface layers reduce the volume of clay dispersed in water, increasing the degree of flocculation of the soil (GASPARETTO et al., 2007), thus, generating good physical conditioning of the soil for the development of plants.

Total porosity, macroporosity, and microporosity (Table 4) presented no significant variation between the treatments and soil depths evaluated.

Table 4. Means for soil density, total porosity, macroporosity, microporosity, hydraulic conductivity, and resistance to penetration of a Eutric Planosol under integrated crop-livestock-forest system.

\begin{tabular}{|c|c|c|c|c|c|c|}
\hline Treatment & SD & $\alpha$ & $\mathrm{Ma}$ & $\mathrm{Mi}$ & $\mathrm{K}_{\theta}$ & $\mathrm{Rp}$ \\
\hline & $\mathrm{kg} \mathrm{dm}^{-3}$ & \multicolumn{3}{|c|}{------------- $\mathrm{m}^{3} \mathrm{~m}^{-3}$------------ } & $\mathrm{cm} \mathrm{h}^{-1}$ & $\mathrm{MPa}$ \\
\hline & \multicolumn{6}{|c|}{$0-0.10 \mathrm{~m}$} \\
\hline GS+BD & $1.24 \mathrm{a}$ & $0.44 \mathrm{a}$ & $0.16 \mathrm{a}$ & $0.28 \mathrm{a}$ & $6.05 \mathrm{a}$ & $0.13 \mathrm{a}$ \\
\hline $\mathrm{MC}+\mathrm{BD}$ & $1.28 \mathrm{a}$ & $0.47 \mathrm{a}$ & $0.16 \mathrm{a}$ & $0.31 \mathrm{a}$ & $13.37 \mathrm{a}$ & $0.14 \mathrm{a}$ \\
\hline $\mathrm{TA}+\mathrm{BD}$ & $1.27 \mathrm{a}$ & $0.45 \mathrm{a}$ & $0.15 \mathrm{a}$ & $0.30 \mathrm{a}$ & $4.36 \mathrm{a}$ & $0.16 \mathrm{a}$ \\
\hline $\mathrm{ZM}+\mathrm{BD}$ & $1.30 \mathrm{a}$ & $0.47 \mathrm{a}$ & $0.15 \mathrm{a}$ & $0.32 \mathrm{a}$ & $6.89 \mathrm{a}$ & $0.14 \mathrm{a}$ \\
\hline $\mathrm{BD}$ & $1.27 \mathrm{a}$ & $0.46 \mathrm{a}$ & $0.15 \mathrm{a}$ & $0.31 \mathrm{a}$ & $4.32 \mathrm{a}$ & $0.15 \mathrm{a}$ \\
\hline \multirow[t]{2}{*}{$\mathrm{CV} \%$} & 6.78 & 6.68 & 21.29 & 11.56 & 157.58 & 59.81 \\
\hline & \multicolumn{6}{|c|}{$0.10-0.20 \mathrm{~m}$} \\
\hline $\mathrm{GS}+\mathrm{BD}$ & $1.39 \mathrm{a}$ & $0.43 \mathrm{a}$ & $0.13 \mathrm{a}$ & $0.30 \mathrm{a}$ & $2.20 \mathrm{a}$ & $0.30 \mathrm{a}$ \\
\hline $\mathrm{MC}+\mathrm{BD}$ & $1.38 \mathrm{a}$ & $0.45 \mathrm{a}$ & $0.14 \mathrm{a}$ & $0.31 \mathrm{a}$ & $3.80 \mathrm{a}$ & $0.21 \mathrm{a}$ \\
\hline $\mathrm{TA}+\mathrm{BD}$ & $1.38 \mathrm{a}$ & $0.44 \mathrm{a}$ & $0.13 \mathrm{a}$ & $0.31 \mathrm{a}$ & $1.00 \mathrm{a}$ & $0.21 \mathrm{a}$ \\
\hline $\mathrm{ZM}+\mathrm{BD}$ & $1.38 \mathrm{a}$ & $0.43 \mathrm{a}$ & $0.13 \mathrm{a}$ & $0.30 \mathrm{a}$ & $4.10 \mathrm{a}$ & $0.29 \mathrm{a}$ \\
\hline BD & $1.39 \mathrm{a}$ & $0.44 \mathrm{a}$ & $0.13 \mathrm{a}$ & $0.31 \mathrm{a}$ & $1.70 \mathrm{a}$ & $0.25 \mathrm{a}$ \\
\hline$\overline{C V} \%$ & 4.74 & 4.78 & 18.61 & 5.03 & 154.68 & 39.02 \\
\hline
\end{tabular}

$\mathrm{SD}=$ Soil Density; $\alpha=$ Total Porosity; Ma = Macroporosity; Mi = Microporosity; K $\theta=$ Saturated hydraulic conductivity; $\mathrm{Rp}=$ Resistance to Penetration. $\mathrm{GS}+\mathrm{BD}=$ Gliricidia sepium + Brachiaria decumbens $; \mathrm{MC}+\mathrm{BD}=$ Mimosa caesalpiniifolia + Brachiaria decumbens $; \mathrm{TA}+\mathrm{BD}=$ Tabebuia alba + Brachiaria decumbens $; \mathrm{ZM}+\mathrm{BD}=$ Zea mays + Brachiaria decumbens; $\mathrm{BD}=$ Brachiaria decumbens. Means followed by the same letters in the columns do not differ by the Tukey's test $(p<0.05)$.

Total porosity varied from 0.43 to $0.47 \mathrm{~m}^{3} \mathrm{~m}^{-3}$. The ideal porosity for good development of plants should be close to $0.50 \mathrm{~m}^{3} \mathrm{~m}^{-3}$ (KIEHL, 1979), thus, most treatments presented total porosity close to the critical limit.

The macroporosity in the $0.0-0.10 \mathrm{~m}$ soil layer of the treatments $\mathrm{GS}+\mathrm{BD}$ and $\mathrm{MC}+\mathrm{BD}$ were above the limit range for plant development, which should be between 0.10 and $0.15 \mathrm{~m}^{3} \mathrm{~m}^{-3}$ (PREVEDELLO, 1996). Macroporosity decreased and microporosity increased with increasing soil clay content, indicating a direct relationship between these attributes.

Soil density was lower in the $0.0-0.10 \mathrm{~m}$ soil 
layer (Table 4); however, it increases with increasing soil depth. Silva et al. (2017a) found similar results in areas under integrated crop-livestock-forest system and reported that the lowest soil densities on the surface layer can be related to the higher root density of the crop sand to the input of soil organic matter contents by this system.

Despite the influence of the textural gradient (IMHOFF et al., 2016), soil density was below the critical limit in all treatments and soil depths evaluated, varying from 1.24 to $1.39 \mathrm{~kg} \mathrm{dm}^{-3}$. According to Reichert et al. (2003), this critical limit for sandy loam soils is 1.70 to $1.80 \mathrm{~kg} \mathrm{dm}^{-3}$; soil densities above this limit hinder plant development due to the lower nutrient absorption caused by the soil resistance to root penetration (TORMENA et al., 2002).

Saturated hydraulic conductivity presented no significant variation between the treatments and soil layers evaluated (Table 4). However, the volume of infiltrated water decreased with increasing soil depth. According to Bortoloni et al. (2016), the low significance of hydraulic conductivity of soils under integrated system may be related to the high variability of this attribute. Assis et al. (2015) evaluated physical attributes of soil under an integrated system and reported that decreases in soil hydraulic conductivity with increasing depth are correlated with decreases in macroporosity and increases in soil microporosity.

According to Fidalski et al. (2015), increase in surface sand content tends to increase hydraulic conductivity and soil water retention, as observed in the present study. However, the increase in soil density decreased infiltrated water volume. Lopes et al. (2007) found a negative correlation between soil density and hydraulic conductivity, because the greater the soil density, the lower its infiltrated water volume.

Soil penetration resistance ranged from 0.13 $\mathrm{MPa}$ to $0.29 \mathrm{MPa}$, however, with no significance differences between treatments and soil layers evaluated (Table 4). The means of resistance to penetration were below the critical limit for plant development 2.0 MPa (REINERT et al., 2008). The resistance to penetration increased with increasing soil density; this increase may be related to decreases in macroporosity due to compaction (TORMENA et al., 2002).

The main factors for soil compaction in integrated systems are the traffic of agricultural machinery and excessive trampling of animals, which can compromise aeration and cause compaction in soils with high moisture. Conte et al. (2009) reported that the increase in soil density through animal trampling does not compromise soil quality, when compared to compaction in a conventional production system, due to the higher degree of resilience promoted by the integrated system, with soil aggregation and recovery of soil structure.

The weighted mean diameter of dry aggregates (WMDda) and weighted mean diameter of wet aggregates (WMDwa) presented no significant variation for the evaluated treatments and layers (Table 5). WMDwa presented the highest means on the surface layer and stood out in the TA+BD treatment with $1.64 \mathrm{~mm}$. The root system of the grasses on the surface layer may have contributed to aggregate formation.

Table 5. Weighted mean diameter of dry aggregates (WMDda), weighted mean diameter of wet aggregates (WMDwa), aggregate stability index (AEI), and total organic carbon (TOC) of a Eutric Planosol under integrated crop-livestock-forest system.

\begin{tabular}{|c|c|c|c|c|}
\hline Treatment & WMDda & WMDwa & AEI & TOC \\
\hline & \multicolumn{3}{|c|}{ 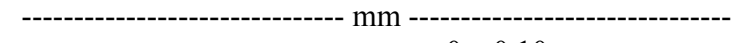 } & $\mathrm{g} \mathrm{kg}^{-1}$ \\
\hline & \multicolumn{4}{|c|}{$0-0.10 \mathrm{~m}$} \\
\hline $\mathrm{GS}+\mathrm{BD}$ & $1.98 \mathrm{a}$ & $1.20 \mathrm{a}$ & $0.61 \mathrm{a}$ & $13.80 \mathrm{a}$ \\
\hline $\mathrm{MC}+\mathrm{BD}$ & $2.28 \mathrm{a}$ & $1.36 \mathrm{a}$ & $0.59 \mathrm{a}$ & $15.63 \mathrm{a}$ \\
\hline $\mathrm{TA}+\mathrm{BD}$ & $2.55 \mathrm{a}$ & $1.64 \mathrm{a}$ & $0.64 \mathrm{a}$ & $15.93 \mathrm{a}$ \\
\hline $\mathrm{ZM}+\mathrm{BD}$ & $2.31 \mathrm{a}$ & $1.16 \mathrm{a}$ & $0.52 \mathrm{a}$ & $16.59 \mathrm{a}$ \\
\hline $\mathrm{BD}$ & $2.23 \mathrm{a}$ & $1.32 \mathrm{a}$ & $0.59 \mathrm{a}$ & $15.99 \mathrm{a}$ \\
\hline $\mathrm{CV} \%$ & 23.89 & 24.88 & 12.16 & 16.08 \\
\hline \multicolumn{5}{|c|}{$0.10-0.20 \mathrm{~m}$} \\
\hline $\mathrm{GS}+\mathrm{BD}$ & $2.83 \mathrm{a}$ & $1.08 \mathrm{a}$ & $0.39 \mathrm{a}$ & $12.98 \mathrm{a}$ \\
\hline $\mathrm{MC}+\mathrm{BD}$ & $2.63 \mathrm{a}$ & $1.10 \mathrm{a}$ & $0.42 \mathrm{a}$ & $12.75 \mathrm{a}$ \\
\hline $\mathrm{TA}+\mathrm{BD}$ & $2.59 \mathrm{a}$ & $1.45 \mathrm{a}$ & $0.59 \mathrm{a}$ & $14.21 \mathrm{a}$ \\
\hline $\mathrm{ZM}+\mathrm{BD}$ & $2.46 \mathrm{a}$ & $0.95 \mathrm{a}$ & $0.39 \mathrm{a}$ & $13.62 \mathrm{a}$ \\
\hline BD & $2.72 \mathrm{a}$ & $1.41 \mathrm{a}$ & $0.52 \mathrm{a}$ & $14.85 \mathrm{a}$ \\
\hline$\overline{C V} \%$ & 13.37 & 17.88 & 19.96 & 16.08 \\
\hline
\end{tabular}

$\mathrm{GS}+\mathrm{BD}=$ Gliricidia sepium + Brachiaria decumbens $; \mathrm{MC}+\mathrm{BD}=$ Mimosa caesalpiniifolia + Brachiaria decumbens; $\mathrm{TA}+\mathrm{BD}=$ Tabebuia alba + Brachiaria decumbens $; \mathrm{ZM}+\mathrm{BD}=$ Zea mays + Brachiaria decumbens; $\mathrm{BD}=$ Brachiaria decumbens; Means followed by the same letters in the columns do not differ by the Tukey's test $(p<0.05)$. 
The $\mathrm{ZM}+\mathrm{BD}$ treatment presented the lowest WMDwa, indicating lower aggregate stability in the plots with maize. The soil turning before the maize planting fractionated larger aggregates into smaller aggregates, decreasing WMDwa.

The aggregate stability index showed the highest means in the $0.0-0.10 \mathrm{~m}$ soil layer, following the same trend of WMDda and WMDwa, varying from 0.39 to $0.61 \mathrm{~mm}$. According to Vezzani and Mielniczuk (2011), aggregate formation is strongly influenced by mechanical action of growing roots and by action of arbuscular mycorrhizal fungi, which may explain the greater aggregate stability on the surface layer.

The treatment with only Brachiaria decumbens (BD) presented a $21 \%$ decrease in aggregate stability index with increasing soil depth, and $\mathrm{TA}+\mathrm{BD}$ presented a decrease of $5 \%$. These results indicate that the presence of species with high $\mathrm{C} / \mathrm{N}$ ratio, such as grasses, assists more on soil aggregation and aggregate stability than legume species, mostly due to their residue decomposition rate. According to Loss et al. (2011), the use of grasses in integrated systems provides good soil cover, which uniforms moisture and leads to a better root system development and greater microbial activity, thus, contributing to the development of a favorable environment to soil aggregation.

The highest means of TOC contents were found on the surface layer (Table 5). Soils with high TOC content are more resistant to anthropogenic actions due to their stability promoted by the cementation and decomposition of residues through microbial activity (NASCIMENTO et al., 2005).

Well-structured soils with good aggregation are more efficient for nutrition and growth of plants and establishment of their root system. Souza et al. (2009) evaluated soil carbon stocks in an integrated crop-livestock system under no tillage and found a contribution of $1.16 \mathrm{Mg} \mathrm{ha}^{-1}$ per year due to the implementation of the system, which improved soil aggregation and particle reorganization.

According to the means of field capacity (FC), permanent wilt point (PWP), and available water (AW) (Table 6), no significant variation $(p<0.05)$ was found for the treatments and depths evaluated.

Table 6. Field capacity (FC), permanent wilt point (PWP), and available water (AW) of a Eutric Planosol under integrated crop-livestock-forest system.

\begin{tabular}{|c|c|c|c|}
\hline Treatment & $\theta \mathrm{FC}$ & $\theta \mathrm{PWP}$ & $\theta \mathrm{AW}$ \\
\hline & \multicolumn{3}{|c|}{ - } \\
\hline & & $0-0.10 \mathrm{n}$ & \\
\hline $\mathrm{GS}+\mathrm{BD}$ & $0.560 \mathrm{a}$ & $0.157 \mathrm{a}$ & $0.403 \mathrm{a}$ \\
\hline $\mathrm{MC}+\mathrm{BD}$ & $0.562 \mathrm{a}$ & $0.159 \mathrm{a}$ & $0.403 \mathrm{a}$ \\
\hline $\mathrm{TA}+\mathrm{BD}$ & $0.561 \mathrm{a}$ & $0.169 \mathrm{a}$ & $0.392 \mathrm{a}$ \\
\hline $\mathrm{ZM}+\mathrm{BD}$ & $0.513 \mathrm{a}$ & $0.173 \mathrm{a}$ & $0.340 \mathrm{a}$ \\
\hline $\mathrm{BD}$ & $0.509 \mathrm{a}$ & $0.176 \mathrm{a}$ & $0.333 \mathrm{a}$ \\
\hline \multirow[t]{2}{*}{$\mathrm{CV} \%$} & 39.12 & 88.54 & 15.30 \\
\hline & & $.10-0.20$ & \\
\hline GS+BD & $0.565 \mathrm{a}$ & $0.163 \mathrm{a}$ & $0.402 \mathrm{a}$ \\
\hline $\mathrm{MC}+\mathrm{BD}$ & $0.568 \mathrm{a}$ & $0.159 \mathrm{a}$ & $0.409 \mathrm{a}$ \\
\hline $\mathrm{TA}+\mathrm{BD}$ & $0.580 \mathrm{a}$ & $0.169 \mathrm{a}$ & $0.411 \mathrm{a}$ \\
\hline $\mathrm{ZM}+\mathrm{BD}$ & $0.636 \mathrm{a}$ & $0.173 \mathrm{a}$ & $0.463 \mathrm{a}$ \\
\hline BD & $0.635 \mathrm{a}$ & $0.176 \mathrm{a}$ & $0.459 \mathrm{a}$ \\
\hline $\mathrm{CV} \%$ & 36.38 & 84.05 & 16.07 \\
\hline
\end{tabular}

$\mathrm{GS}+\mathrm{BD}=$ Gliricidia sepium + Brachiaria decumbens $; \mathrm{MC}+\mathrm{BD}=$ Mimosa caesalpiniifolia + Brachiaria decumbens; $\mathrm{TA}+\mathrm{BD}=$ Tabebuia alba + Brachiaria decumbens $; \mathrm{ZM}+\mathrm{BD}=$ Zea mays + Brachiaria decumbens $; \mathrm{BD}=$ Brachiaria decumbens; Means followed by the same letters in the columns do not differ by the Tukey's test $(p<0.05)$.

Barbosa et al. (2017) evaluated soil physical attributes in an agroforestry system in Santa Catarina, Brazil, and found that the amount of compact aggregates and the increase in microporosity volume had a positive effect on soil water storage capacity, corroborating with the data found by the present study. Moreover, Suzuki et al. (2008) evaluated the soil susceptibility to compaction in Rio Grande do Sul, Brazil, and found a reduction in volumetric moisture with increasing clay content and decreasing soil density.

The highest water volumes of FC, PWP, and AW were found in the layer with higher soil density. Silva et al. (2017b) evaluated soil physical quality through the retention curve and found that soil density has a positive effect on soil water storage capacity and that this effect is higher than that of the organic matter. In the present study, the significant 
values of available water found in the $0.10-0.20 \mathrm{~m}$ layer indicate a higher water retention and storage in this layer due to its microporosity and higher soil density.

Magalhães et al. (2015) used water retention curve to evaluate integrated production systems and found lower water retention and lower available water to plants with increasing tension in the 0.0 $0.10 \mathrm{~m}$ layer. This may be related to the greater macroporosity on the surface layer, which, according to Hillel (1971), loses the water retained by capillarity more easily at low tensions.

Information on the interrelationships between water, soil, and plant is essential for an efficient agriculture because the water necessary to vegetal growth is mainly in the soil and fundamentally depends on its physical properties (AGUIAR NETTO et al., 1999). Therefore, the use of management practices that contribute to the maintenance of water in the soil is necessary to maintain a balanced system and promote a good plant development.

Integrated systems increase soil organic matter content and plant cover throughout most part of the year, assisting in the soil hydraulic conductivity and water storage, even in drought periods, minimizing the impacts caused by water stress.

\section{CONCLUSIONS}

The evaluated integrated crop-livestock-forest systems (ICLF) presented no significant variation in soil water availability, despite the increase in soil organic carbon in the evaluated period;

The ICLF promoted no significant improvement in the physical attributes of the Eutric Planosol soil after a three-year period.

In the third year after the implementation of the ICLF, they presented no effects that improved soil aggregate stability and porous space, indicating the need for a longer evaluation time.

\section{REFERENCES}

AGUIAR NETTO, A. O. et al. Avaliação do conceito de capacidade de campo para um Latossolo Amarelo coeso do estado da Bahia. Revista Brasileira de Ciência do Solo, v. 23, n. 3, p. 661667, 1999.

ALMEIDA, K. S. S. A. et al. Models for moisture estimation in different horizons of a yellow Argisol using TDR. Semina: Ciências Agrárias, v. 38, n. 4, p. 1727-1736, 2017.

ASSIS, P. C. R. et al. Atributos físicos do solo em sistemas de integração Lavoura-Pecuária-Floresta. Revista Brasileira de Engenharia Agrícola e Ambiental, v. 19, n. 4, p. 309-316, 2015.

BALBINO, L. C. et al. Evolução tecnológica e arranjo produtivo de sistemas de integração lavourapecuária-floresta no Brasil. Pesquisa Agropecuária Brasileira, v. 46, n. 10, p. 1-12, 2011.

BARBOSA, J. S. et al. Atributos físico-hídricos de um Cambissolo Húmico sob sistema agroflorestal no planalto catarinense. Floresta e Ambiente, v. 24, n. 1, p. 1-9, 2017.

BORTOLONI, D. et al. Propriedades físicas do solo em sistema de integração Lavoura-Pecuária-Floresta em Cambissolo Húmico. Revista de Ciências Agroveterinárias, v. 15, n. 1, p. 60-67, 2016.

CARPENEDO, V.; MIELNICZUK, J. Estado de agregação e qualidade de agregados de Latossolos roxos, submetidos a diferentes sistemas de manejo. Revista Brasileira de Ciência do Solo, v. 14, n. 1, p. 99-105, 1990.

CONTE, O. et al. Evolução de atributos físicos do solo em sistemas de integração lavoura-pecuária. Pesquisa Agropecuária Brasileira, v. 46, n. 10, p. 1301-1309, 2009.

COSTA, M. A. T. et al. Resistência do solo à penetração e produção de raízes e de forragem em diferentes níveis de intensificação do pastejo. Revista Brasileira de Ciência do Solo, v. 36, n. 3, p. 993-1004, 2012.

DONAGeMA, G. K et al. Manual de métodos de análises de solo. 2. ed. Rio de Janeiro, RJ: EMBRAPA, 2011.212 p.

FACCIN, F. C. et al. Frações granulométricas da matéria orgânica do solo em consórcio com milho safrinha e capim-marandu sob fontes de nitrogênio. Pesquisa Agropecuária Brasileira, v. 51, n. 12 , p. 2000-2009, 2016.

FERREIRA, D. F. Análises estatísticas por meio do SISVAR para Windows versão 4.0. In: REUNIÃO ANUAL DA REGIÃO BRASILEIRA DA SOCIEDADE INTERNACIONAL DE BIOMETRIA, 40., 2000, São Carlos. Anais... São Carlos: UFSC, 2000.

FIDALSKI, J. Qualidade física de Latossolo Vermelho em sistema de integração lavoura-pecuária após cultivo de soja e pastejo em braquiária. Pesquisa Agropecuária Brasileira, v. 50, n. 11, p. 1097-1104, 2015.

GASPARETTO, E. C. G. et al. Grau de floculação 
da argila de um Latossolo Vermelho utilizado com lavoura e mata nativa. Synergismus Scyentifica, v. 4, n. 1, p. 1-3, 2007.

HILLEL, D. Soil and water: Physical principles and process. 1. ed. New York: Academic Press. $1971.304 \mathrm{p}$.

IMHOFF, S. et al. Physical quality indicators and mechanical behavior of agricultural soils of Argentina. PLoS ONE, v. 11, n. 4, p. 1-21, 2016.

KIEHL, E. J. Manual de edafologia: Relações soloplanta. 1. ed. São Paulo, SP: Agronômica Ceres, 1979. $262 \mathrm{p}$.

KICHEL, A. N. et al. Recuperação de pastagens degradadas com uso de sistemas de integração e o potencial agropecuário no Mato Grosso do Sul. In: BUNGENSTAB, D. J. (Ed.). Sistemas de integração lavoura pecuária floresta: A produção sustentável. Campo Grande, MS: Embrapa Gado de Corte, 2011. v. 2, cap. 1, p. 2-11.

KLEIN, C.; KLEIN, V. A. Estratégias para potencializar a retenção e disponibilidade de água no solo. Revista Eletrônica em Gestão, Educação e Tecnologia Ambiental, v. 19, n. 1, p. 21-29, 2015.

LOPES, R. A. P. et al. Propriedades físicas de Latossolo Vermelho distroférrico típico sob sistemas de manejo na sucessão soja-milho no período de três anos. Acta Scientiarum. Agronomy, v. 29, sup., p. $721-727,2007$.

LOSS, A. et al. Agregação, Carbono e Nitrogênio em agregados do solo sob plantio direto com integração Lavoura-Pecuária. Pesquisa Agropecuária Brasileira, v. 46, n. 10, p. 1269-1276, 2011.

LOSS, A. et al. Atributos físicos e químicos do solo em sistemas de consórcio e sucessão de lavoura, pastagem e silvipastoril em Santa Teresa, ES. Bioscience Journal, v. 30, n. 5, p. 1347-1357, 2014.

MAGAlHÃES, W. A. et al. Curva de retenção de água do solo como indicador da qualidade física em sistema sintegrados de produção. In: CONGRESSO BRASILEIRO DE CIÊNCIA DO SOLO, 35., 2015, Natal. Anais... Natal: Sociedade Brasileira de Ciência do Solo, 2015. p. 1-4.

NASCIMENTO, J. T. et al. Efeito de leguminosas nos atributos físicos e carbono orgânico de um Luvissolo. Revista Brasileira de Ciência do Solo, v. 29 , n. 5 , p. $825-831,2005$.

PREVEDELLO, C. L. Física do solo com problemas resolvidos. 1 ed. Curitiba, PR: Salesward-discovery, 1996. 446 p.
RANGEL, J. H. A. et al. Integração Lavoura Pecuária Floresta na região Nordeste do Brasil. Ciência Veterinária Tropical, v. 19, n. 3, p. 75-84, 2016.

REICHERT, J. M. et al. Qualidade dos solos e sustentabilidade de sistemas agrícolas. Ciência e Ambiente, v. 27, n. 2, p. 29-48, 2003.

REINERT, D. J. Limites críticos de densidade do solo para crescimento de raízes de plantas de cobertura em Argissolo Vermelho. Revista Brasileira de Ciência do Solo, v. 32, n. 5, p. 18051816, 2008.

SANTOS, H. G. et al. Sistema Brasileiro de Classificação de Solos. 3. ed. rev. ampl. Brasília, DF: Embrapa, 2013a. 353 p.

SANTOS, J. L. et al. Caracterização física e química de um Planossolo localizado no semiárido Baiano. Agropecuária Científica no Semiárido, v. 9, n. 3, p. 13-17, 2013 b.

SERRA, A. P. et al. Fundamentos técnicos para implantação de sistemas de integração lavourapecuária-floresta com eucalipto. In: BUNGENSTAB, D. J. (Ed.). Sistemas de integração lavoura-pecuária-floresta: a produção sustentável. 2 ed. Brasília, DF: Embrapa, 2012. cap. 5, p. 49-72.

SILVA, A. R. et al. Atributos físicos e disponibilidade de carbono do solo em sistemas de integração lavoura-pecuária-floresta (ILPF) homogêneo e Santa Fé, no estado do Pará, Brasil. Agropecuária Técnica, v. 37, n. 1, p. 96-104, 2016.

SILVA, A. S. et al. Argila e matéria orgânica e seus efeitos na agregação em diferentes usos do solo. Ciência Rural, v. 44, n. 10, p. 1783-1789, 2014.

SILVA, É. A. et al. Qualidade física de um Latossolo estimada por estudos das curvas de retenção de água, indicadores de fácil determinação e "índice S". Tecnologia \& Ciência Agropecuária, v. 11, n. 4, p. 49-54, 2017 b.

SILVA, I. F.; MIELNICZUK, J. Ação do sistema radicular de plantas na formação e estabilização de agregados. Revista Brasileira de Ciência do Solo, v. 21, n. 2, p. 113-117, 1997.

SILVA, M. P. et al. Plantas de cobertura e qualidade química e física de Latossolo Vermelho distrófico sob plantio direto. Revista Brasileira de Ciências Agrárias, v. 12, n. 1, p. 60-67, 2017a.

SOUZA, E. D. et al. Estoques de Carbonoo rgânico e de Nitrogênio no solo em sistema de integração 
Lavoura-Pecuária em plantio direto, submetido a intensidades de pastejo. Revista Brasileira de Ciência do Solo, v. 33, n. 6, p. 1829-1836, 2009.

SUZUKI, L. E. A. S. et al. Estimativa da susceptibilidade à compactação e do suporte de carga do solo com base em propriedades físicas de solos do rio grande do sul. Revista Brasileira de Ciência do Solo, v. 32, n. 3, p. 963-973, 2008.

TISDALL, J. M. et al. The stability of soil aggregates as affected by organic materials microbial activity and physical disruption. Australian Journal of Soil Research, v. 16, n. 1, p. 9-17, 1978.

TORMENA, C. A. et al. Densidade, Porosidade e resistência a penetração em Latossolo cultivado sob diferentes sistemas de preparo do solo. Scientia Agricola, v. 59, n. 4, p. 795-801, 2002.

VEZZANI, F. M.; MIELNICZUK, J. Agregação e estoque de Carbono em Argissolo submetido a diferentes práticas de manejo agrícola. Revista Brasileira de Ciência do Solo, v. 35, n. 1, p. 213223, 2011. 